\title{
ORDER AND CULTURE PASSAGES OF POPULARIZATION
}

\section{Marie-Louise von Plessen}

I will try to draw a portrait of the political genesis of the museum as a popular institution for national thought and education by examining Europe's first National Museums: the British Museum, the Louvre, the Versailles Museum of the History of France and those museums characterized by an early expression of nationalist feeling before the political institution of the nation state emerged. Their influence grew from enlightened philosophy and they became, in spite of their aspiration of objectivity, major teachers of minor and later pupils.

According to Krzysztof Pomian's definition the significance of the term Nation in museum history can have two meanings: up to the 18th century 'nation' means participation in universal topics, after 1800 'nation' means a specific territory, a people, a cultural context.

The antiquarian culture from the 16th to the 18 th century was widely based in important private and royal collections of local and ethnic antiquities that, by change of definition, became national antiquities as relics and sources of thought and reflection of ethnic finality. The first royal property transferred to the state for all time was to be the acquisition by the Swedish King Gustav III of his mother's collection of paintings after her death in 1777.

The change from collector to maecenas marks the transition of interest from crown to state. By way of founding museums and making them accessible to the public, dynastic thought and political stability were perpetuated. Before the accessibility of museums, the only places where people could contemplate fine works of art were churches. Once these works of art were removed from their ecclesiastical context, they became aesthetic objects. A fine example is Museo Pio Clementino, housing the Pope's collection in the Vatican which was founded in 1784 in Rome. In 1809 the Prado Museum was founded, and established as an institution for the exhibition of paintings from

... the collections of several schools; therefore we take from all public institutions including our Palaces, paintings accordingly to serve as models and guide for our talents to glorify the merits of Spanish painting.

Paintings from the Prado collection were also taken from secularized monasteries and other royal palaces. Ten years later, in 
261819 , the new museum was inaugurated by King Ferdinand VII as a private museum with only 11 registered artefacts. When he died, in 1833, it remained royal property. In 1868, at the end of Queen Isabella's reign, about 2.000 out of 3.000 artefacts were exhibited.

As early as 1781 Joseph II opened his Vienna Imperial galleries in the Belvedere palace to visitors three times a week; anyone who entered was asked to leave cane and sword at the entrance. Most museums at that time restricted access to travellers with a recommendation or to people of rank and birth. Apart from a general knowledge of art, greatly improved through copies, prints and casts of sculptures, patriotism helped to bring alive the process of museum making. An outstanding example of academic thought conditioned by patriotic sentiment is Count Caspar Sternberg's offering of his collections to the people of Bohemia. When Count Ferenc Széchényi dedicated the Museum Hungaricum to the Hungarian people, he rather pompously called it an altar ordained to Hungarian science. His goal, although coming much later, parallelled the Polish Sejm's project to create a Musaeum Polonicum in 1775 as a scientific institution devoted to the interests of both art and science, animated by the encyclopedians and the example of the British Museum. But the division of Poland put an end to these ambitious plans. After 1809 the princely collections of the Krakow Cartorisky family became the source of a patriotic collection of historical items nourishing Polish morale and keeping up elite confidence after such great losses of national identity.

In 1848, both the Budapest and the
Prague museums became temples of opposition and upheaval in the Habsburg empire and ambitious symbols of the achievement of national independence and civil rights rather than academic centres of art and scholarly research. This political mainlining of liberal thought was not the intention of the private maecenas Freiherr Hans von Aufsess of Nuremberg, whose collections helped to create the German National Museum in 1852. Aufsess favoured the apolitical idea of a museum based on the historical sources of German antiquities and history, as a national institute for

... all Germans to preserve and enlarge their knowledge of the German past, and especially to save the monuments of German history, art and literature from sinking into oblivion.

Even after 1871, the German National Museum did not become a Reich institution with all the heroic paintings of battles, victorious events or military heroes. It remained a national museum according to Schiller's definition of 'the national' as a unique characteristic of the people.

National ideologies enter museology along with political struggles throughout the 19th century. Obvious products of this process are the Italian Risorgimento Museums. In the Scandinavian countries this is also true for ethnographic museums like the Nordiska museet founded in 1873, the open-air museum Skansen founded in 1891 and the Folkemuseum, Copenhagen, founded in 1885. In Germany the equivalent would be the Heimatmuseen, in France the Musées communaux.

To school a growing industrial society in national principles, the museum, rather 
than print or other visual media, spread the national ideology as an educational programme, just as local museums build up the patriotic spirit by contributing to mass education. The idea of a public museum, created by revolutionary principles, corresponds to the cultural mission of a nation and the conservation of its own identity, materializing and resulting in written sources and three-dimensional artefacts. Even today our need to question and understand popular culture depends on a better comprehension of traditions and their integration into daily life and work.

During this age of nationalism, museums invested in progress and change. The two major conditions for this development were: firstly, a strong sense of identity before and during the constitution of the nation state after the Congress of Vienna and of a new territorial order throughout Central and Northern Europe and, secondly, the physical existence of valuable collections of patriotic and national interest.

These conditions applied to the first of all the European national museums, today the preferred term is 'universal institution': the British Museum, founded in 1753, seven years after the Prince of Wales had expressed to Sir Hans Sloane how great the pleasure would be

... to see so magnificent a collection in England, esteeming it an ornament to the nation; and expressed his sentiments how much it must conduce to the benefit of learning, and how great an honour will rebound to Britain, to have it established for public use to the late posterity.

'Posterity' and 'public use' became the columns supporting an idea that grew right from the beginning, when the British Parliament decided on the foundation of the British Museum in 1753. Sir Hans Sloane dedicated his collections to the British nation on two conditions: that the state should pay an apanage to his daughters of 20.000 pounds sterling and should provide a museum building. In order to finance this project, the British state established a lottery - common practice for such large investments. As a result of the universal and encyclopedian spirit of French enlightenment philosophers, it was made a principle furthermore that only the government should appoint the directorship of the British museum. It was to be administered on the nation's behalf by trustees obliged to adhere to these fundamental principles in an honourable way: the collections were not to be divided, they should be open to public use with no entrance fee charged for the pleasure and study of the artefacts. The series of inventory catalogues reach back to the 18th century. Later on, the British Museum's collections were enlarged by many donations which created several new sections such as the ethnographical department, true to the major principle: conservation of our own cultural heritage means conservation of the cultural heritage of all the world. The British Museum, therefore, became something of a temple of scientific research, and there is no way any director would be willing to return the artefacts reclaimed by their many countries of origin.

In France the development that led to the National Museum was quite different. The Louvre, first opened to the public with Louis XVI's collection in October 1750 to present good examples and 
models for actual creations of fine and applied arts, had become by 1778 the Musée de Luxembourg. Later it justified the zeal of the young French nation in collecting the legitimate heritage of beauty herself and in maintaining first place in the universal republic of letters, art and science. After the Directoire period the Louvre museum yielded to the revolution and after that to the Napoleonic mission when the National Convention dedicated it to the people in 1793 as the National Museum. In 1804 the Louvre's name was changed to Musée Napoléon, becoming more and more of an imperialistic museum that proclaimed the political utopia of a Europe of nation states rather than pronouncing and presenting republican ideals. The imperial period mainly worked to deepen nationalist feelings in the patriotic mind by means of visual art, especially paintings.

From 1744, the enlightened scholar Comte d'Angerviller operated behind the opening of the Louvre as a National monument. True to his encyclopedian mind he even dealt with the technical problems of presentation, lighting, architecture and framing. In 1794, one year after opening to the public, the Louvre received the trophies of many earlier wars to enrich its collections. After the Congress of Vienna several curators, sanctioned by diplomatic treaties, sought to return stolen works of art to their rightful owners, a problem that has become highly relevant in our own times. Since the fall of communism the curtains of museum depositories have been lifted, and we can investigate the extent to which many works of art migrated throughout Europe during the last phases of the Second
World War.

In October 1792 the Minister of the Interior, Roland, stated to the painter David that the Louvre collections should

... express the development of the great treasures of the nation, attract foreigners, improve the quality of fine arts, please art amateurs and offer studies to artists, and all people have the right to enjoy this pleasure.

The Louvre was to belong to the whole nation, regardless of profession, birth or rank, as Roland put it in a letter:

The Museum will profoundly impress the intellect; it will become a most powerful means to honour the French Republic.

In such a statement the museum becomesentirely bound up with the ideas of freedom, revolution and progress.

Despite this ideological approach to the revolutionary dogma, the items for exhibition were not selected according to ideological criteria, since David Fragonard, an altogether apolitical painter became curator in the middle of the jacobine epoch. The glory and prestige of the Louvre Museum was meant to popularize the ideas of the young republic.

The parisian Musée de Cluny became another popular museum. It was opened to the public in 1844 by the National Assembly. Reflecting the interest in the Middle Ages at the time, it was to house the collection of the antiquarian Sommerard. The opening of the museum of National Antiquitites, Le Musée des Monuments Francais followed in 1862, closing the gap between the cosmopolitan ambition of the Louvre and the Cluny 
Museum. It was also to instruct the French about the origins of their culture and artistic tradition and, primarily, to serve the "res publica" as an institution of national property.

Louis Philippe's Galerie des Batailles was no longer dedicated to improving collective thought and national unity through the principles of the revolutionaries. The 33 paintings of gigantic dimensions were installed in 1837 in the Versailles Museum of the History of France. They were to depict the "glory of France" from past epochs to the present. The last painting in the series most significantly showed French people transferring their power to the king who received his crown by constitutional law: this corresponded to an actual political programme establishing the constitutional power of royal rule untrammelled by republican participation - it was an exhibition of national pride, defense of France, her territory and her ideals for the purpose of nourshing patriotic feelings.

Emperor Frans Josef was not in the least bothered by constitutional law when he opened the Kunsthistorisches Museum in Vienna in 1891 for the sake of monuments of Art and Antiquities. By imperial act he finally made accessible to his people the very fine and most outstanding collection of his Habsburg ancestors. In the 1890s the average number of visitors each year was as high as 350,000 up to 500,000 ! During the reign of the Empress Maria Theresia the first order of scientific and social criteria for the immense collections was established. The first director general was also appointed to supervise the royal and imperial treasure chambers, galleries and other precious artefacts. In 1808 the first classification of the collections was published in two volumes. In 1813 two opening days per week were granted to the public on payment of an entrance fee; during the Napoleonic wars the collection was pillaged, but was opened to the participants of the Congress of Vienna. After the foundation of collections dealing with national history and culture in several Habsburg crownlands - in Budapest 1801, Graz 1811, Innsbruck 1827 and Linz 1833 - the imperial court passed a law in Vienna that the collections of the Kunsthistorisches Museum were at no time to be divided or split up but were to be administered as one entity. In spite of the great popular esteem it enjoyed the Kunsthistorisches Museum was never meant to induce a sense of identity but rather an historical conscience and loyalty to the imperial house and the Habsburg Empire. Finally it was to be a Gesamtkunstwerk of historicism, true to the dynasty's European cultural heritage.

In Denmark the idea of a national museum grew from the Kunstkammer, founded in 1660 by King Frederic III. Its funds originated from several departments of the cabinet of curiosities, and also formed the basis for new museums such as the Museum of Northern Antiquities in 1816, the Ethnographic collection, opened to the public in 1841, the collection of classic antiquities, coins and medals. Slott Rosenborg was in fact the first chronologically organized museum in the world. Meant to be the historical account of Danish Royalty, it was opened to the public in 1854 . When J. C. Jacobsen proposed and partly financed the first Danish national museum in Frederiksborg as a museum of Danish national history, inau- 
30 gurated in 1878 , his principal guide was Louis Philippe's Museum of the History of France in Versailles. He wished to make the duties that cultural heritage would demand from present and future generations an obligation. To this end he wanted to bring life into and spread historical knowledge. This comprehension of the museum's task should improve the Danish kingdom's self-esteem and morale for the destiny of such a small nation.

The founder's program clearly shows the moral and educational nature of their aims, the result of an essential national feeling after the Danish defeat in 1864.

Before Frederiksborg's program of cultural education by way of national heritage, the Danish National Museum, founded in 1807, also followed a French example mentioned before: Alexandre Lenoir's Museum of French Antiquities of 1793, a mere product of enlightenment. The Danish National Museum was to be a pantheon of Danish men and women; it was to link royal interests to the rising tide of the liberal middle class, to shape patriotic thought and to allow the study of Danish national history through mainly archaeological and ethnographical objects. In 1819 it was opened to the public only once a week from $11 \mathrm{am}$ to $1 \mathrm{pm}$. It took a long time for the museum to achieve at its present state of dialogue with the people!

As we can see from the given examples, ideology and the program of the nation state depended heavily on the successful visualisation of national heritage to build up patriotism and its integration into the nation state. Museums were opened to a growing public that participated more and more in political conflicts and opposition by relating their exhibitions to the stan- dards of governing stabilities, in fact even to enforce stability. From the depositories that developed along with changing principles of stability one can conclude that no museum ever corresponded to the real Zeitgeist it tried to illustrate. Its means were conditioned to show passages and no actual standpoints. Only in this meaning did public museums succeed in becoming popular institutions for established ideals, mostly in contradiction to their originators' enlightened programme of revolutionary thought.

\section{NOTE}

I am gratefully obliged to all those who contributed their lectures to the symposium I organized with the Berlin German Historical Museum in May 1991 entitled 'The Nation and Her Museums'.

Marie-Louise von Plessen är utställningsledare och ställforreträdande cheffor Deutsches Historisches Museum, Berlin. Studier i sociologi och historia $i$ Mïnchen, Dr phil 1975.

Adr: Deutsches Historisches Museum, Windscheidstrasse 18, D-1000 Berlin 12. 